\title{
Prosthecobacter fusiformis gen. and sp. nov., nom. rev.
}

\author{
JAMES T. STALEY, J. A. M. DE BONT, AND KLAASKE DE JONGE \\ Department of Microbiology and Immunology, School of Medicine, University of Washington, Seattle, \\ Washington 98195
}

The names Prosthecobacter Staley et al. and Prosthecobacter fusiformis Staley et al., were not included in the recently published Approved Lists of Bacterial Names and hence have no standing in bacteriological nomenclature. However, these names are here revived for the same organisms with which they were originally associated and, by this action, now have valid status.

The bacterial names in Table 1 were published before 1 January 1980 , but they were not validly published because they were not announced in the International Journal of Systematic Bac. teriology in accord with Rule 27 of the Bacteriological Code (1). Therefore, these names were not included in the recently published Approved Lists of Bacterial Names (2). The purpose of this communication is to effect the revival of these names and thus to give them valid status.

\section{LTERATURE CITED}

1. Lapage, S.P., P.H.A. Sneath, E.F. Lessel, V.B.D. Skerman, H.P.R. Seeliger, and W.A. Clark. 1975 International code of nomenclature of bacteria. 1976 Revision. Association of Microbiological Societies by the American Society for Microbiology, Washington, D.C.

2. Skerman, V.B.D., V. McGowan, and P.H.A. Sneath (ed). 1980. Approved lists of bacterial names. Int. J. Syst. Bacteriol. 30:255-420.

3. Staley, J.T., J.A.M. deBont, and K. deJonge. 1976 Prosthecobacter fusiformis, nov. gen. et sp., the fusiform caulobacter. Antonie van Leeuwenhoek J. Microbiol. Serol. 42:333-342.

TABLE 1. List of bacterial names to be revived and accorded valid publication status

\begin{tabular}{|c|c|c|c|c|}
\hline Name & Proposed as & $\begin{array}{l}\text { Authors of original pub- } \\
\text { lication }\end{array}$ & $\begin{array}{l}\text { Literature citation to } \\
\text { previous description } \\
\text { and proposal of name }\end{array}$ & Nomenclatural type $e^{a}$ \\
\hline $\begin{array}{l}\text { Prosthecobacter } \\
\text { Prosthecobacter } \\
\text { fusiformis }\end{array}$ & $\begin{array}{l}\text { New genus } \\
\text { New species }\end{array}$ & $\begin{array}{l}\text { Staley et al. } \\
\text { Staley et al. }\end{array}$ & $\begin{array}{l}3 \\
3\end{array}$ & $\begin{array}{l}\text { P. fusiformis } \\
\text { Strain FC4 (= ATCC } \\
25309)\end{array}$ \\
\hline
\end{tabular}

\footnotetext{
${ }^{a}$ ATCC, American Type Culture Collection, Rockville, Md.
} 